NASA/TM-2005-213869

\title{
Status of the NEXT Ion Thruster Long Duration Test
}

Michael M. Frandina and Lynn A. Arrington

QSS Group, Inc., Cleveland, Ohio

George C. Soulas, Tyler A. Hickman, and Michael J. Patterson

Glenn Research Center, Cleveland, Ohio 
Since its founding, NASA has been dedicated to the advancement of aeronautics and space science. The NASA Scientific and Technical Information (STI) Program Office plays a key part in helping NASA maintain this important role.

The NASA STI Program Office is operated by Langley Research Center, the Lead Center for NASA's scientific and technical information. The NASA STI Program Office provides access to the NASA STI Database, the largest collection of aeronautical and space science STI in the world. The Program Office is also NASA's institutional mechanism for disseminating the results of its research and development activities. These results are published by NASA in the NASA STI Report Series, which includes the following report types:

- $\quad$ TECHNICAL PUBLICATION. Reports of completed research or a major significant phase of research that present the results of NASA programs and include extensive data or theoretical analysis. Includes compilations of significant scientific and technical data and information deemed to be of continuing reference value. NASA's counterpart of peerreviewed formal professional papers but has less stringent limitations on manuscript length and extent of graphic presentations.

- TECHNICAL MEMORANDUM. Scientific and technical findings that are preliminary or of specialized interest, e.g., quick release reports, working papers, and bibliographies that contain minimal annotation. Does not contain extensive analysis.

- CONTRACTOR REPORT. Scientific and technical findings by NASA-sponsored contractors and grantees.
- CONFERENCE PUBLICATION. Collected papers from scientific and technical conferences, symposia, seminars, or other meetings sponsored or cosponsored by NASA.

- SPECIAL PUBLICATION. Scientific, technical, or historical information from NASA programs, projects, and missions, often concerned with subjects having substantial public interest.

- TECHNICAL TRANSLATION. Englishlanguage translations of foreign scientific and technical material pertinent to NASA's mission.

Specialized services that complement the STI Program Office's diverse offerings include creating custom thesauri, building customized databases, organizing and publishing research results ... even providing videos.

For more information about the NASA STI Program Office, see the following:

- Access the NASA STI Program Home Page at http://www.sti.nasa.gov

- E-mail your question via the Internet to help@sti.nasa.gov

- Fax your question to the NASA Access Help Desk at 301-621-0134

- Telephone the NASA Access Help Desk at 301-621-0390

- Write to:

NASA Access Help Desk

NASA Center for AeroSpace Information 7121 Standard Drive

Hanover, MD 21076 
NASA/TM-2005-213869

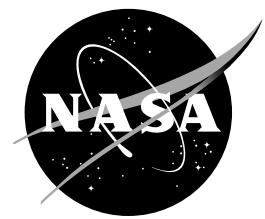

\section{Status of the NEXT Ion Thruster Long Duration Test}

Michael M. Frandina and Lynn A. Arrington

QSS Group, Inc., Cleveland, Ohio

George C. Soulas, Tyler A. Hickman, and Michael J. Patterson

Glenn Research Center, Cleveland, Ohio

Prepared for the

41st Joint Propulsion Conference and Exhibit

cosponsored by the AIAA, ASME, SAE, and ASEE

Tucson, Arizona, July 10-13, 2005

National Aeronautics and

Space Administration

Glenn Research Center 


\section{Acknowledgments}

The authors would like to thank the technicians and facility personnel that worked on the significant undertaking of constructing a new vacuum facility along with fabricating the necessary support equipment required for the NEXT Long Duration Test (LDT).

Available from

NASA Center for Aerospace Information 7121 Standard Drive

Hanover, MD 21076
National Technical Information Service 5285 Port Royal Road Springfield, VA 22100

Available electronically at http:/ /gltrs.grc.nasa.gov 


\title{
Status of the NEXT Ion Thruster Long Duration Test
}

\author{
Michael M. Frandina and Lynn A. Arrington \\ QSS Group, Inc. \\ Cleveland, Ohio 44135 \\ George C. Soulas, Tyler A. Hickman, and Michael J. Patterson \\ National Aeronautics and Space Administration \\ Glenn Research Center \\ Cleveland, Ohio 44135
}

\begin{abstract}
The status of NASA's Evolutionary Xenon Thruster (NEXT) Long Duration Test (LDT) is presented. The test will be conducted with a $36 \mathrm{~cm}$ diameter engineering model ion thruster, designated EM3, to validate and qualify the NEXT thruster propellant throughput capability of $450 \mathrm{~kg}$ xenon. The ion thruster will be operated at various input powers from the NEXT throttle table. Pretest performance assessments demonstrated that EM3 satisfies all thruster performance requirements. As of June 26, 2005, the ion thruster has accumulated 493 hours of operation and processed $10.2 \mathrm{~kg}$ of xenon at a thruster input power of $6.9 \mathrm{~kW}$. Overall ion thruster performance, which includes thrust, thruster input power, specific impulse, and thrust efficiency, has been steady to date with very little variation in performance parameters.
\end{abstract}

\section{Introduction}

The success of the NASA Solar Electric Propulsion Technology Applications Readiness (NSTAR) program's ion propulsion system on the Deep-Space 1 spacecraft has secured the future for ion propulsion technology for other NASA missions (refs. 1 and 2). While the $2.3 \mathrm{~kW} \mathrm{NSTAR} \mathrm{ion} \mathrm{thruster} \mathrm{input} \mathrm{power} \mathrm{and} \mathrm{service} \mathrm{life} \mathrm{capabilities} \mathrm{are}$ appropriate for Discovery Class as well as other, smaller NASA missions, the application of NSTAR hardware to more demanding missions such as outer planet explorers and sample return missions is limited due its lack of power and total impulse capability. As a result, NASA's Office of Space Science awarded a development project to a NASA Glenn Research Center (GRC)-led team to develop the next generation ion propulsion system (refs. 3 and 4 ). The propulsion system, called NASA's Evolutionary Xenon Thruster (NEXT), consists of a $36 \mathrm{~cm}$ beam extraction diameter ion thruster, a lightweight, modular power processing unit with an efficiency and a specific mass equal-to or better-than the NSTAR power processor, and a xenon feed system that will significantly reduce mass and volume relative to the NSTAR feed system. Ion thruster performance requirements include a specific impulse of at least $4050 \mathrm{~s}$ at full power and a thruster efficiency of greater than 0.63 at full power. Regarding service life, the ion thruster must provide a $185 \mathrm{~kg}$ baseline requirement and a $300 \mathrm{~kg}$ nominal mission requirement xenon throughput capability. Therefore, based on the nominal mission requirement, the ion thruster must provide a $450 \mathrm{~kg}$ qualification throughput (ref. 5). The first wear test of a NEXT ion thruster was for a 2038 hour duration at full power and processed $43 \mathrm{~kg}$ of xenon (ref. 6). The service life capability of the NEXT ion thruster is being assessed by thruster wear tests and life-modeling of critical thruster components, such as the ion optics and cathodes.

The maximum thruster input power level was chosen for the first $300 \mathrm{~kg}$ of propellant throughput because lifemodeling predicted that this power level will cause the most severe thruster erosion. The objectives of the LDT include: characterizing thruster operation and performance over the duration of the test; identifying thruster lifelimiting phenomena; and measuring thruster component wear rates and comparing them with that predicted from life models. In addition, after $300 \mathrm{~kg}$ propellant throughput has been achieved the thruster will be throttled into a design reference mission profile until qualification level propellant throughput has been demonstrated (ref. 5). This paper presents the status of the NEXT LDT. A description of the test article is discussed followed by a description of the test support hardware, which includes the power console, gas feed system, vacuum facility, and diagnostics. The test operating condition is then described. Finally, wear test results to date are presented and discussed.

\section{Test Article}

The wear test is being conducted with an engineering model ion thruster, designated EM3, which is shown in figure 1. The thruster utilizes a $36 \mathrm{~cm}$ beam extraction diameter, which yields approximately 1.6 times the area of the NSTAR ion thruster. The technical approach here is a continuation of the "derating" philosophy used for the 
NSTAR ion thruster. A beam extraction area 1.6 times that of the NSTAR ion thruster beam area allows operation at significantly higher thruster input power while maintaining low voltages and ion current densities. Thus, potential complications associated with high voltage electrode operations are avoided, and thruster longevity can be maintained. The discharge chamber design of EM3 utilizes a hollow cathode electron emitter and a semi-conic chamber with a ring cusp magnetic circuit for electron containment created by high strength, rare earth magnets. A flake retention scheme is employed in the discharge chamber, which also acts as a magnet retainer. The material, preparation, and installation processes employed for the flake-retention system are identical to those implemented on the NSTAR thruster (ref. 7). The discharge chamber also incorporates a reverse-feed propellant injection process for the main plenum. Finally, EM3 utilizes new compact propellant isolators with a higher voltage isolation capability (about $1800 \mathrm{~V}$ ) than those used by the NSTAR thruster. The ion thruster utilizes a neutralizer design that is mechanically similar to the Hollow Cathode Assembly of the International Space Station Plasma Contactor (ref. 8). Because the neutralizer cathode emission current range on the NEXT ion thruster is similar to that of the Plasma Contactor Hollow Cathode Assembly, the NEXT neutralizer design can leverage the large cathode database already available with this design for risk reduction (ref. 9). The ion optics' are a set of prototype model hardware manufactured by Aerojet (ref. 10). The mounting assembly of EM3 is similar to that of the NEXT ion thruster EM1, which was used in the NEXT 2000 Hour Wear Test (ref. 6). The performance of the EM1 ion optics electrode geometry has been described in detail (ref. 11).

\section{Test Support Hardware}

\section{A. Power Console}

A power console similar to that described in reference 12 and used in reference 6 powers the ion thruster. This power console utilizes commercially available power supplies that allow for ion thruster input powers of over $10 \mathrm{~kW}$ with beam power supply voltages of up to $2000 \mathrm{~V}$.

\section{B. Gas Feed System}

A high purity gas feed system is used to provide xenon to the discharge cathode and neutralizer cathode through separate mass flow controllers. For the main plenum, xenon is provided either through a separate mass flow controller or through an engineering model propellant management system kernel provided by Aerojet (ref. 13).

\section{Vacuum Facility}

The wear test is being conducted in Vacuum Facility 16 at NASA GRC, shown in figure 2. This $2.7 \mathrm{~m}$ diameter $8.5 \mathrm{~m}$ long facility has a bell jar on the end cap, which can be isolated from the main body of the facility. In case of an emergency the thruster could be withdrawn into the bell jar. Vacuum Facility 16 is evacuated with 10 cryogenic pumps, with an additional cryogenic pump on the isolated bell jar for emergency use. For this test, the facility pressure is monitored by two ionization gages, with one located in the facility about $0.5 \mathrm{~m}$ radially beside the ion thruster and the second located on the cylindrical section of the facility wall about $0.5 \mathrm{~m}$ downstream of the ion thruster. In addition, the isolated bell jar has an ion gage that is turned off during normal operation. The facility base pressure has been less than $3.3 * 10^{-5} \mathrm{~Pa}\left(2.5^{*} 10^{-7}\right.$ Torr $)$. Facility background pressure during thruster operation at full power has been $3.3 * 10^{-4} \mathrm{~Pa}\left(2.5^{*} 10^{-6}\right.$ Torr $)$ next to the ion thruster. The facility pumping speed on xenon calculated with this ion gage is approximately $170,000 \mathrm{~L} / \mathrm{s}$. The facility interior surfaces downstream of the ion thruster are lined with a carbon material to reduce the amount of facility material that is backsputtered onto the ion thruster. The backsputter rate is determined with a quartz crystal microbalance located next to the ion thruster. The backsputter rate during wear testing has typically been about 3 microns/kh.

\section{Diagnostics}

A computerized data acquisition and control system is used to monitor ion thruster and facility operations. Data are sampled at a frequency range of 10 to $20 \mathrm{~Hz}$ and is stored once per minute. Ion thruster currents and voltages are measured with current shunts and voltage dividers, respectively, and recorded. Facility pressures and individual mass flows to the ion thruster are also sampled and recorded. In addition, the thruster is periodically connected to an electrically floating power supply circuit used to determine the screen grid transparency to discharge chamber ions. The circuit electrically ties the screen grid to the discharge cathode during normal operation, but during this diagnostic the grid is biased negative relative to discharge cathode potential to repel electrons and measure the collected ion current.

Ion beam diagnostics and erosion diagnostics are also included in this test and are described in a companion paper (ref. 14). 


\section{Operating Condition and Performance Tests}

The NEXT ion thruster is designed for solar electric propulsion applications. Ion thruster input power is, therefore, designed to be throttled from 0.5 to $6.9 \mathrm{~kW}$. For the LDT, it is necessary to demonstrate the thruster's propellant throughput capability at an operating point that causes the most severe and stressful thruster operation in addition to demonstrating performance at several throttle table operating points. The highest thruster input power, which corresponded to a $1800 \mathrm{~V}$ beam power supply voltage and a $3.52 \mathrm{~A}$ beam current, was therefore selected as the wear test operating condition for the first $300 \mathrm{~kg}$ propellant throughput. The NEXT LDT thruster full power operating point is listed in table 1. Prior to and throughout the wear test, performance tests are conducted on the thruster and thruster components. Thruster performance tests include measuring thruster operating parameters and determining thruster performance at several of the power levels in the throttle table. Component performance assessments are periodically made on the discharge chamber, ion optics, and neutralizer cathode. Ion optics performance includes electron backstreaming, perveance, and screen grid ion transparency measurements (ref. 15). Discharge chamber performance is assessed by measuring discharge losses as a function of discharge propellant utilization efficiency at fixed discharge voltages. Finally, neutralizer performance, which included keeper voltage measurements as a function of neutralizer flow, is assessed.

\section{Test Results and Discussions}

As of June 26, 2005, NEXT thruster EM3 has accumulated 493 hours of operation at a thruster input power of $6.9 \mathrm{~kW}$. There have been a total of 4 unintended test interruptions; however, none were caused by abnormal thruster operation.

\section{A. Pretest Performance Results}

Table 2 lists some of the pretest ion thruster performance results along with the beginning of life throttle table values at various operating conditions. For thrust calculations in table 2, the beam divergence thrust correction factor and the total doubly-to-singly-charged ion current ratio were assumed to be in the 0.962 to 0.974 and 0.028 to 0.060 ranges, respectively, based on the methodology developed for NSTAR thrusters (ref. 16). Ingested mass flow due to the facility background gas pressure was included in the total mass flow rate to the thruster for determining thrust efficiency and specific impulse (ref. 17). The demonstrated throttling range was 0.5 to $6.9 \mathrm{~kW}$, with a resulting thrust of about $26 \mathrm{mN}$ at low power to $237 \mathrm{mN}$ at the wear test full power point. The corresponding specific impulse range was 1360 to $4160 \mathrm{~s}$. Thrust efficiencies were between about 0.319 at low power to 0.706 at the wear test full power point.

Along with thruster performance data, pretest discharge chamber and neutralizer performance were also determined. Figure 3 shows discharge losses as a function of discharge chamber propellant utilization efficiency for all throttle table and wear test beam currents. At each beam current, the ratio of main to discharge cathode flow rate was adjusted to maintain the nominal discharge voltage. Ingested mass flow due to the facility background gas pressure was included in the calculation of discharge propellant utilization efficiency. All data, except for the lowest power point, were obtained for a beam power supply voltage of $1179 \mathrm{~V}$. This voltage was chosen both because it was the lowest voltage that was common to all beam currents in table 1, except the lowest power point, and it also provided the highest discharge losses. At each of these beam currents, discharge losses were recorded between utilization efficiencies of about 0.85 to 0.95 when possible. As shown in figure 2, discharge losses at beam currents between $2.70 \mathrm{~A}$ and $3.52 \mathrm{~A}$ were within $10 \mathrm{~W} / \mathrm{A}$ throughout all propellant utilization efficiencies examined. Discharges losses increased more significantly for the 1.00, 1.20 and 2.00 A beam currents.

Figure 4 shows neutralizer keeper voltage as a function of flow rate for several beam currents for both EM3 and EM1 (ref. 18). Data were measured at a beam power supply voltage of $1800 \mathrm{~V}$. The lowest flow value for each curve was either in plume mode, which is defined here as a peak-to-peak neutralizer keeper voltage oscillation of greater than $5 \mathrm{~V}$, or was the last point taken due to a power supply failure. For all neutralizer flow rates and beam currents $(\mathrm{Jb}), \mathrm{EM} 3$ has a higher neutralizer voltage of up to about $1 \mathrm{~V}$. The figure indicates that for the $4.01 \mathrm{sccm}$ neutralizer flow for the full power LDT operating condition there is at least $2.0 \mathrm{sccm}$ flow margin between the nominal operating flow and plume mode operation.

\section{B. Wear Test Results}

The LDT began when full power operation was first initiated. During the first few hours, performance tests were conducted at the full power point. For all wear test results presented, data recorded during performance testing have been removed to demonstrate the thruster's behavior as function of time, not as a function of varying input values. 


\section{Thruster Performance}

Thruster performance parameters of value to mission planners include thrust, input power, efficiency, and specific impulse. Thrust and input power as a function of time are plotted in figures 5 and 6 , respectively. Thrust was determined as described in the prior section. Thrust has remained steady at $237 \mathrm{mN} \pm 2 \mathrm{mN}$. Input power has remained steady at $6.85 \mathrm{~kW} \pm 0.05 \mathrm{~kW}$.

Specific impulse and thrust efficiency as a function of time are plotted in figures 7 and 8, respectively. All thruster mass flow rates, which are used to calculate thrust efficiency and specific impulse, have been within \pm 1 percent of their nominal set points since hour 94 of the LDT. Before hour 94, the neutralizer cathode flow rate was set at a value that was higher than the throttle table value. Since then, specific impulse and thrust efficiency have been $4180 \mathrm{~s} \pm 30 \mathrm{~s}$ and $0.710 \pm 0.005$, respectively. Variations in performance have been less than \pm 1 percent of the nominal values.

\section{Discharge Chamber}

Discharge current and voltage as a function of time are shown in figures 9 and 10, respectively. The discharge current is adjusted as needed to maintain a constant beam current of $3.52 \mathrm{~A} \pm 0.01 \mathrm{~A}$. As the figure shows, changes with time have generally been less than 3 percent of the nominal run values. The only noted trend, while small, has been with the discharge current, which rose from a nominal start value of about $18.5 \mathrm{~A}$ to about $18.9 \mathrm{~A}$ by hour 350 . Discharge voltages to date have been $23.2 \mathrm{~V}+0.4 /-0.3 \mathrm{~V}$. Discharge losses, shown in figure 11 , increased from $123 \mathrm{~W} / \mathrm{A}$ to about $124 \mathrm{~W} / \mathrm{A}$ by hour 350 . This change is within the measurement uncertainty. The relatively constant discharge losses over 350 hours is contrasted with that exhibited by the NSTAR thruster. In three separate wear tests, NSTAR thruster discharge losses increased by 10 to 15 W/A within the first 500 hours of wear testing (refs. 19 to 21). The initial change in the NEXT thruster discharge losses was very small and this contributes to a more constant thruster input power, and, therefore, a more constant thrust efficiency at beginning of life.

\section{Neutralizer}

Neutralizer keeper current as a function of time is plotted in figure 12. Neutralizer keeper currents to date have been $3.00 \mathrm{~A} \pm 0.02 \mathrm{~A}$. Neutralizer keeper voltage as a function of time is plotted on figure 12. Since the neutralizer flow was adjusted after hour 94, the neutralizer keeper voltages to date have been $11.1 \mathrm{~V}+0.1 /-0.3 \mathrm{~V}$. The neutralizer keeper voltage exhibits voltage "spikes", as shown in figure 13. These voltage "spikes" correspond to thruster restarts, which is similar to NSTAR neutralizer behavior (refs. 16, 17, and 19). Coupling voltage, which is a measure of neutralizer cathode potential relative to vacuum facility ground, is plotted in figure 14 as a function of time. The coupling voltage has been steady since hour 94 at $-10.2 \mathrm{~V}+0.3 /-0.1 \mathrm{~V}$. The low coupling voltage magnitude is due to the high keeper current and the considerable neutralizer flow margin selected for operation. These high values were selected to ensure neutralizer operation in spot mode throughout ion thruster service life while imposing only modest sacrifices in thruster performance. Both the neutralizer keeper and coupling voltage variations indicate no degradation of neutralizer performance to date.

\section{Ion Optics}

Accelerator grid current as a function of time is plotted in figure 15. The accelerator current decreased from a start value of about $16 \mathrm{~mA}$ to about $14.2 \mathrm{~mA}$ by hour 94 . The cause of the decrease is threefold. First, from test start to hour 49 the vacuum facility had only 9 of the 10 cryopumps operating which caused a higher background pressure that in turn caused a higher accelerator current. Second, the thruster experienced a burn in period that is typical to NEXT thrusters. Finally, at hour 94 the neutralizer flow was reduced which caused a lower background pressure that in turn caused a lower accelerator current. Since hour 94 the accelerator currents have been steady at $14.2 \mathrm{~mA}$ $+0.5 /-0.2 \mathrm{~mA}$. The "spikes" in the accelerator current correlate with thruster recycles. Immediately following a thruster recycle, the accelerator current returns to an increased value. The current then decreases gradually for up to 10 minutes to its nominal value. This behavior may be the result of grid cooling during a recycle. During a thruster recycle, the discharge power is momentarily reduced so that when high voltage is re-applied, another recycle is not inadvertently triggered. It is speculated that this momentary reduction in discharge power allows the ion optics to cool enough to change the hot grid gap, thus changing the accelerator current by a small amount. Regardless of the cause, these accelerator current "spikes" are not considered harmful to thruster operation. Beginning-of-life accelerator currents for the NEXT thruster were about 13 percent higher than nominal accelerator currents and reached nominal values within about 94 hours. NSTAR thruster accelerator currents generally started higher-thannominal and required up to 1500 hours to decrease to nominal values (refs. 20 and 21). Accelerator voltage as a function of time is plotted in figure 16 . The accelerator voltages have been steady at $-210 \mathrm{~V} \pm 2 \mathrm{~V}$.

Correcting thruster recycles by removing those occurring during performance testing yields 283 total thruster recycles as of hour 493. The recycle rate as a function of time is plotted in figure 17. The recycle rate has always been less than 1.5 recycles per hour. In comparison, the NSTAR 8200 hour wear test operated with an average recycle rate of 1 to 2 per hour (ref. 20). It was expected that the NEXT thruster should have a slightly higher average 
recycle rate than the NSTAR thruster because the NEXT thruster's beam extraction area and inter-grid electric field are $1.6 \mathrm{X}$ and $1.5 \mathrm{X}$ that of the NSTAR thruster, respectively. Impingement-limited total voltages, electron backstreaming limits, and screen grid ion transparencies throughout the wear test are plotted in figures 18, 19, and 20 , respectively. Impingement-limited total voltages were determined from plots of accelerator current as a function of total ion extraction voltage where the slope was $-0.02 \mathrm{~mA} / \mathrm{V}$ (ref. 15). Electron backstreaming limits were determined by lowering the magnitude of the accelerator grid voltage until the indicated beam current increased by $1 \mathrm{~mA}$ due to backstreaming electrons. Screen grid ion transparencies were calculated in the same manner as previous NEXT thruster testing (ref. 11). To date, impingement limited total voltages have been steady at 830 to $880 \mathrm{~V}$, electron backstreaming limits have been steady at -176 to $-175 \mathrm{~V}$, and screen grid ion transparencies have been steady at 0.89 to 0.90 . All three of these performance parameters indicate no significant ion optics' performance degradation.

\section{Conclusion}

The LDT is being conducted with a $36 \mathrm{~cm}$, engineering model NEXT ion thruster EM3. As of June 26, 2005, NEXT thruster EM3 has accumulated about 493 hours of operation at a thruster input power of $6.9 \mathrm{~kW}$. Pretest ion thruster performance was determined over a throttling range of 0.5 to $6.9 \mathrm{~kW}$, with resulting thrusts of about $26 \mathrm{mN}$ at low power to $237 \mathrm{mN}$ at the full power point. The corresponding specific impulse range was 1360 to $4160 \mathrm{~s}$. Thrust efficiencies were between about 0.319 at low power to 0.706 at full power. Pretest results demonstrated that EM3 satisfies all thruster performance requirements. Discharge chamber, neutralizer, and ion optics operation during the wear test was evaluated. Discharge losses increased by less than 1 percent during the first 493 hours. Neutralizer keeper and coupling voltages have been steady, with no indication of performance degradation. Impingement limited total voltages, electron backstreaming limits, and screen grid ion transparencies have also been steady, with no indication of performance degradation. Overall ion thruster performance, which includes thrust, thruster input power, specific impulse, and thrust efficiency, has been steady to date. Variations in performance have been less than \pm 1 percent of nominal values.

\section{References}

1. Rawlin, V.K., et al., “An Ion Propulsion System for NASA's Deep Space Missions,” AIAA Paper 99-4612, September 1999.

2. Polk, J.E., et al., "In-Flight Performance of the NSTAR Ion Propulsion System on the Deep Space One Mission," IEEE Aerospace Conference Proceedings 8.0304, March 2000.

3. Patterson, M.J., et al., "NEXT: NASA's Evolutionary Xenon Thruster Development Status," AIAA Paper 20034862, July 2003.

4. Patterson, M.J., et al., "NEXT: NASA's Evolutionary Xenon Thruster," AIAA Paper 2002-3832, July 2002.

5. Oh, D., et al, "Deep Space Mission Applications for NEXT: NASA's Evolutionary Xenon Thruster," AIAA Paper 2004-3806, July 2004.

6. Soulas, G.C., et al., "NEXT Ion Engine 2000 Hour Wear Test Results," AIAA Paper 2004-3791, July 2004.

7. Christensen, J.A., et al., "Design and Fabrication of a Flight Model $2.3 \mathrm{~kW}$ Ion Thruster for the Deep Space 1 Mission," AIAA Paper 98-3327, July 1998.

8. Patterson, M.J., et al., "Space Station Cathode Design, Performance, and Operating Specifications," IEPC Paper 97-170, August 1997.

9. Kovaleski, S.K., et al., "A Review of Testing of Hollow Cathodes for the International Space Station Plasma Contactor," IEPC Paper 01-271, October 2001.

10. Hoskins, W., "Design and Fabrication of the NEXT Prototype Model Ion Thruster," AIAA Paper 2005-3885, July 2005.

11. Soulas, G.C., et al., "Performance Evaluation of $40 \mathrm{~cm}$ Ion Optics for the NEXT Ion Thruster," AIAA Paper 2002-3834, July 2002.

12. Pinero, L.R., et al., "Power Console Development for NASA's Electric Propulsion Outreach Program," IEPC Paper 93-250, September 1993.

13. Aadland, R.S., et al., "Development Status of the NEXT Propellant Management System," AIAA Paper 20043974, July 2004.

14. Hickman, T.A., et al., "Overview of Diagnostics for the NEXT Long Duration Test," AIAA Paper 2005-4064, July 2005.

15. Soulas, G.C., et al., "Performance Evaluation of the NEXT Ion Engine," AIAA Paper 2003-5278, July 2003.

16. Patterson, M.J., et al., "Performance of the NASA $30 \mathrm{~cm}$ Ion Thruster," IEPC Paper 93-108, September 1993. 
17. Sovey, J.S., "Improved Ion Containment Using a Ring-Cusp Ion Thruster," Journal of Spacecraft and Rockets, vol. 21, no. 5, September-October 1984, p. 489.

18. Soulas, G.C., et al., "Status of the NEXT Ion Engine Wear Test," AIAA Paper 2003-4863, July 2003.

19. Polk, J.E., et al., "A 1000-Hour Wear Test of the NASA NSTAR Ion Thruster," AIAA Paper 96-2717, July 1996.

20. Polk, et al., "An Overview of the Results from an 8200 Hour Wear Test of the NSTAR Ion Thruster," AIAA Paper 99-2446, June 1999.

21. Anderson, J.R., et al., "Results of an On-going Long Duration Ground Test of the DS1 Flight Spare Ion Thruster," AIAA Paper 99-2857, June 1999.

TABLE 1.-NEXT LDT OPERATING POINT

\begin{tabular}{|c|c|c|c|c|c|c|c|}
\hline $\begin{array}{l}\text { Engine Input } \\
\text { Power }^{\mathrm{a}}, \mathrm{kW}\end{array}$ & $\begin{array}{c}\text { Beam Current, } \\
\text { A }\end{array}$ & $\begin{array}{l}\text { Beam Power } \\
\text { Supply } \\
\text { Voltage, V }\end{array}$ & $\begin{array}{l}\text { Accelerator } \\
\text { Voltage, V }\end{array}$ & $\begin{array}{c}\text { Main Plenum } \\
\text { Flow Rate } \\
\text { sccm }\end{array}$ & $\begin{array}{c}\text { Discharge } \\
\text { Cathode Flow } \\
\text { Rate }^{b}, \text { sccm }\end{array}$ & $\begin{array}{c}\text { Neutralizer } \\
\text { Cathode Flow } \\
\text { Rate }^{\mathrm{c}}, \mathrm{sccm}\end{array}$ & $\begin{array}{c}\text { Neutralizer } \\
\text { Keeper } \\
\text { Current, A }\end{array}$ \\
\hline 6.83 & 3.52 & 1800 & -210 & 49.64 & 4.87 & 4.01 & 3.00 \\
\hline
\end{tabular}

aNominal Values

${ }^{b}$ Main-to-discharge cathode flow split selected to result in a 23.5-27 V discharge voltaqe

TABLE 2.-NEXT THRUSTER EM3 PRETEST PERFORMANCE RESULTS AT VARIOUS BEGINNING OF LIFE THROTTLE TABLE OPERATING CONDITIONS

\begin{tabular}{|c|c|c|c|c|c|c|c|}
\hline & $\begin{array}{c}\text { Beam Current, } \\
\text { A }\end{array}$ & $\begin{array}{c}\text { Beam Power } \\
\text { Supply } \\
\text { Voltage, V }\end{array}$ & $\begin{array}{l}\text { Thruster Input } \\
\text { Power, kW }\end{array}$ & $\begin{array}{l}\text { Discharge } \\
\text { Losses, W/A }\end{array}$ & $\begin{array}{c}\text { Thrust } \\
\text { Efficiency }\end{array}$ & Thrust, $\mathrm{mN}$ & $\begin{array}{c}\text { Specific } \\
\text { Impulse, s }\end{array}$ \\
\hline $\begin{array}{r}\text { Performance test result } \\
\text { Throttle table value }\end{array}$ & $\begin{array}{r}1.00 \\
1.00\end{array}$ & 275 & $\begin{array}{rr}0.54 & \\
& 0.53 \\
\end{array}$ & 209 & $\begin{array}{r}0.328 \\
0.331\end{array}$ & 26 & $\begin{array}{r}1400 \\
1400\end{array}$ \\
\hline $\begin{array}{l}\text { Performance test result } \\
\text { Throttle table value }\end{array}$ & $\begin{array}{ll}1.20 & \\
1.20\end{array}$ & $\begin{array}{r}1801 \\
1800\end{array}$ & $\begin{array}{r}2.44 \\
2.43\end{array}$ & 187 & $\begin{array}{r}0.641 \\
0.647\end{array}$ & 80 & $\begin{array}{r}3980 \\
4000\end{array}$ \\
\hline $\begin{array}{l}\text { Performance test result } \\
\text { Throttle table value }\end{array}$ & $\begin{array}{r}2.01 \\
2.00\end{array}$ & $\begin{array}{r}1800 \\
1800\end{array}$ & $\begin{array}{rr}3.97 & \\
& 4.00 \\
& \end{array}$ & 153 & $\begin{array}{r}0.710 \\
0.707\end{array}$ & $\begin{array}{ll}134 & \\
& 134\end{array}$ & $\begin{array}{r}4290 \\
4310\end{array}$ \\
\hline $\begin{array}{l}\text { Performance test result } \\
\text { Throttle table value }\end{array}$ & $\begin{array}{r}3.54 \\
3.52\end{array}$ & $\begin{array}{r}1801 \\
1800\end{array}$ & $\begin{array}{r}6.84 \\
6.83\end{array}$ & 124 & $\begin{array}{r}0.706 \\
0.710\end{array}$ & $\begin{array}{ll}237 & \\
& 236\end{array}$ & $\begin{array}{r}4160 \\
4190\end{array}$ \\
\hline
\end{tabular}

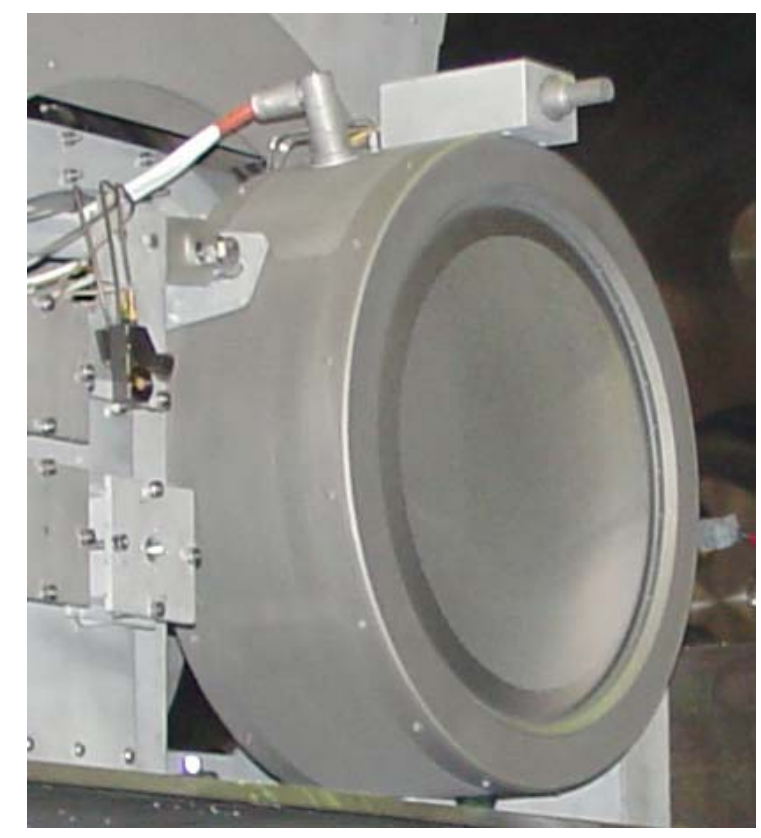

Figure 1.- NEXT engineering model thruster EM3. 


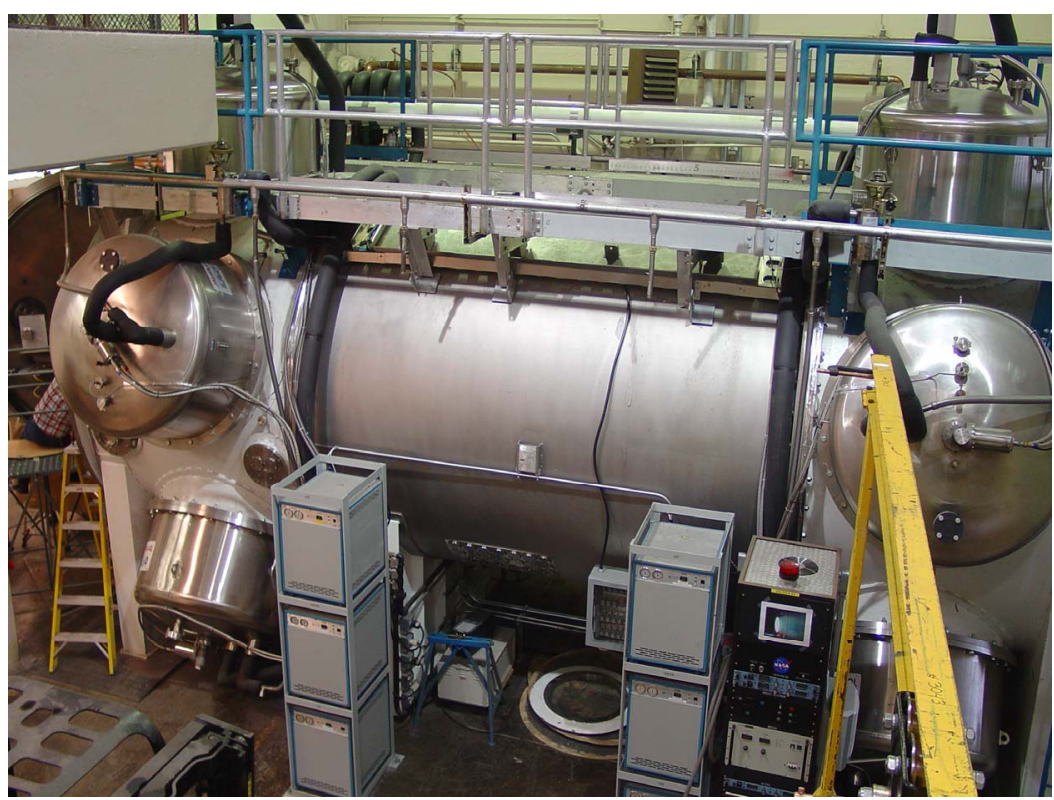

Figure 2.-NASA Glenn Research Center Vacuum Facility 16.

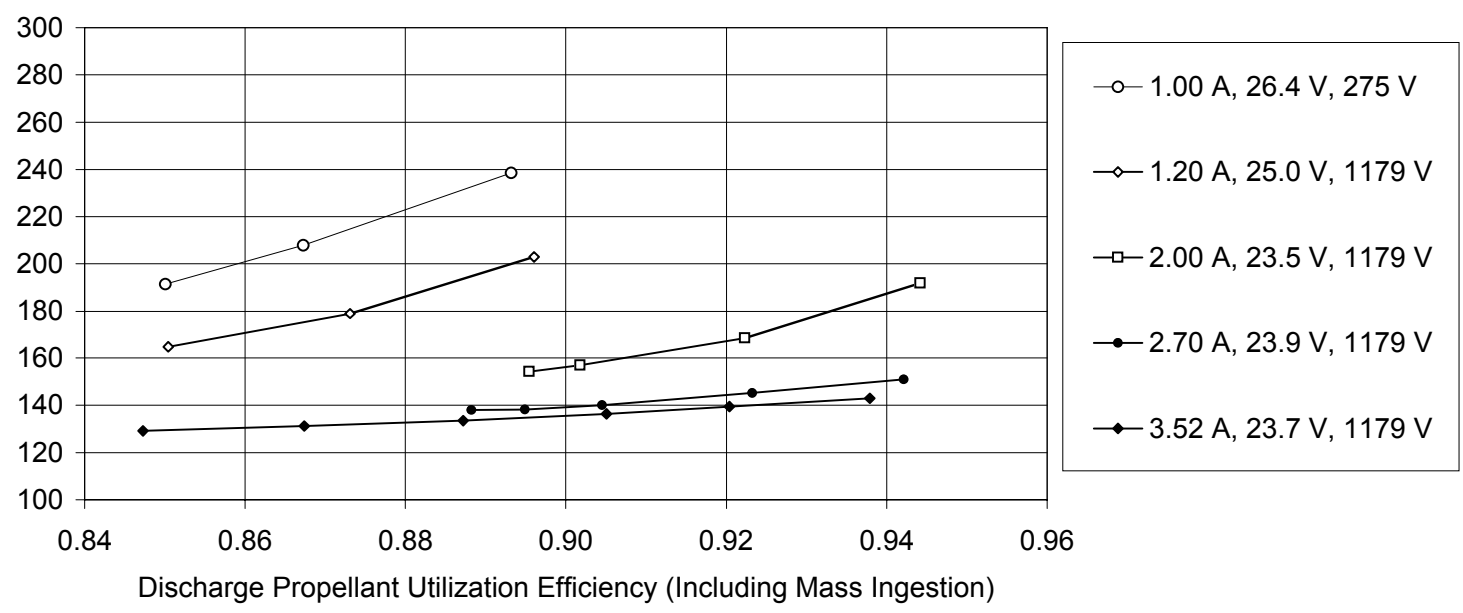

Figure 3.-Discharge losses as a function of discharge propellant utilization efficiency for all beam currents. 


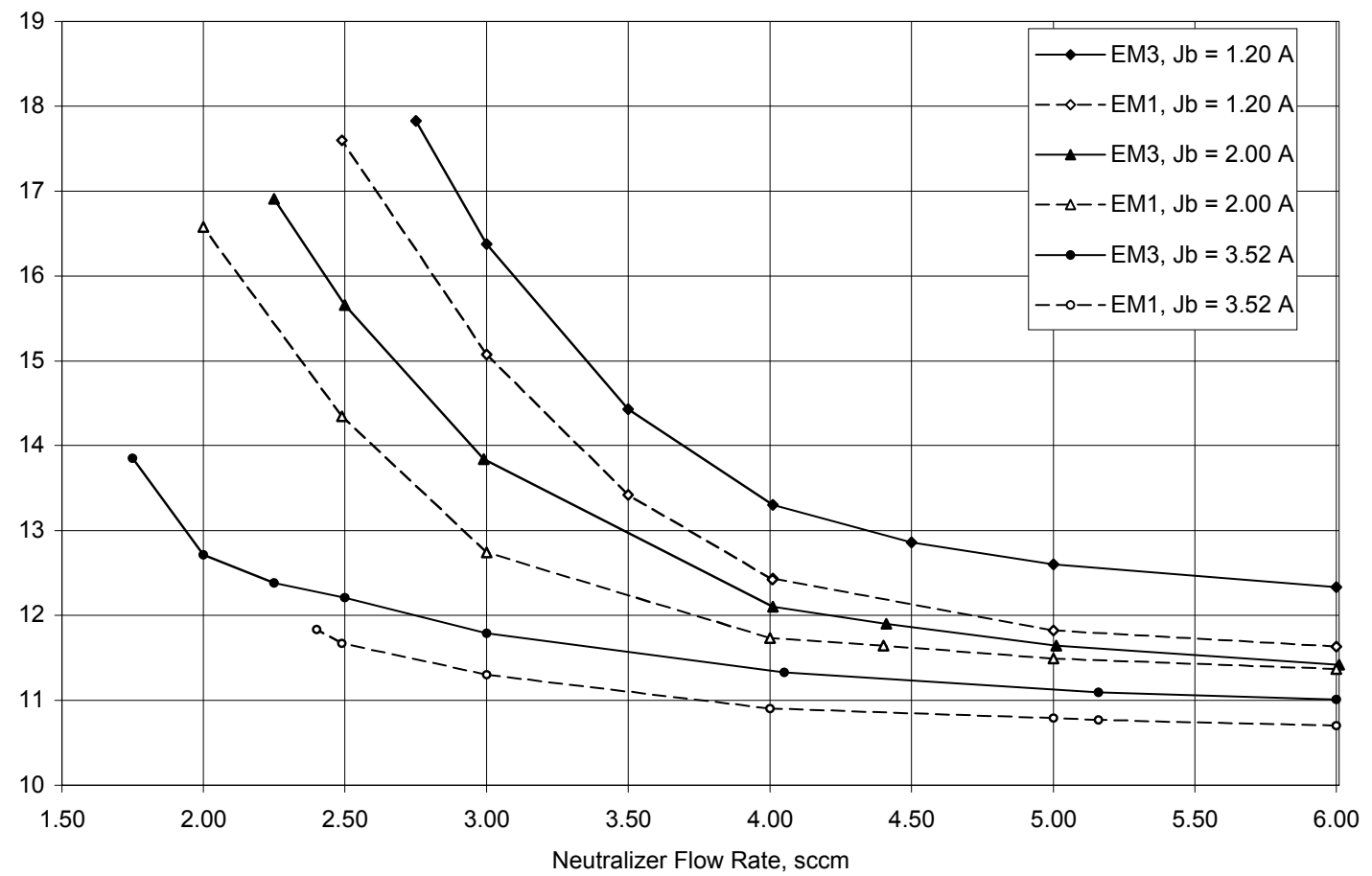

Figure 4.- Neutralizer keeper voltage as a function of flow rate for EM1 and EM3 with all beam currents at a beam power supply voltage of $1800 \mathrm{~V}$.

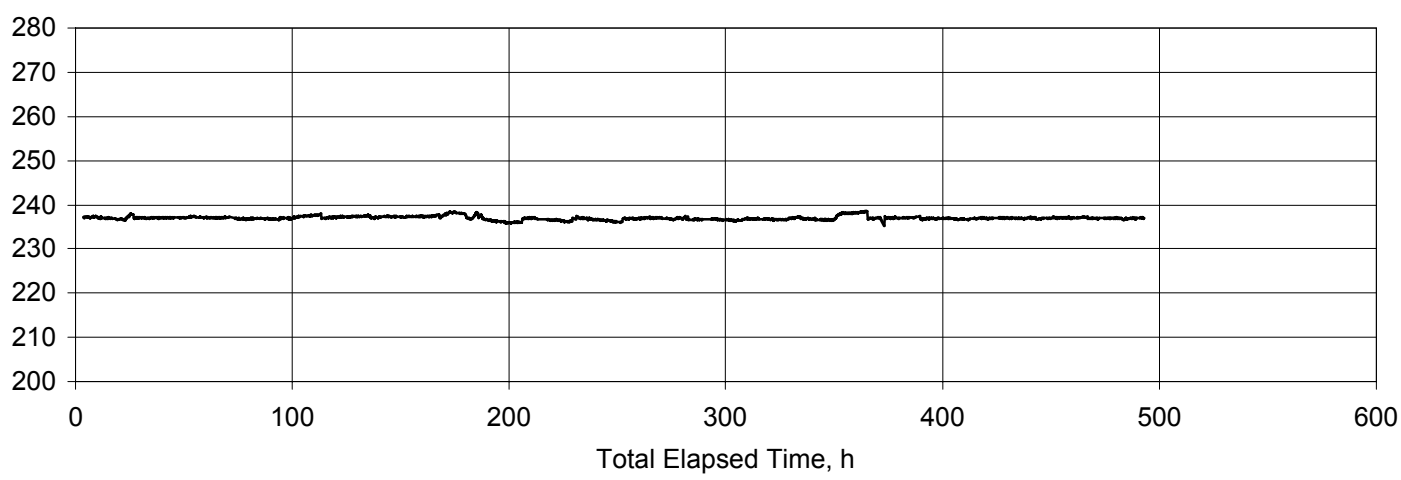

Figure 5.-Calculated thrust as a function of time.

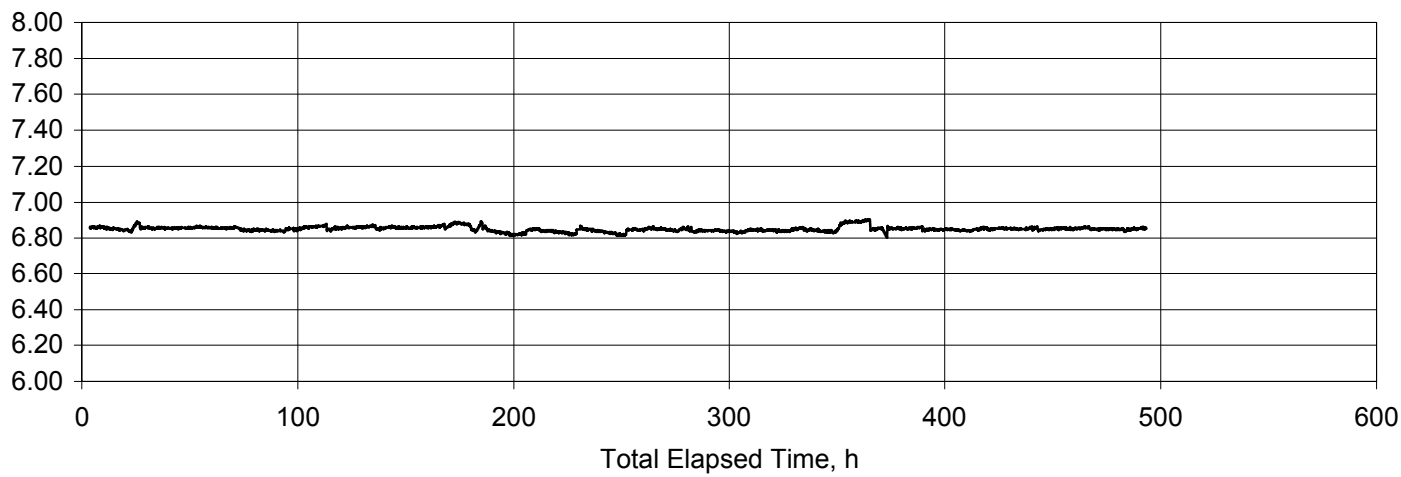

Figure 6.-Thruster input power as a function of time. 


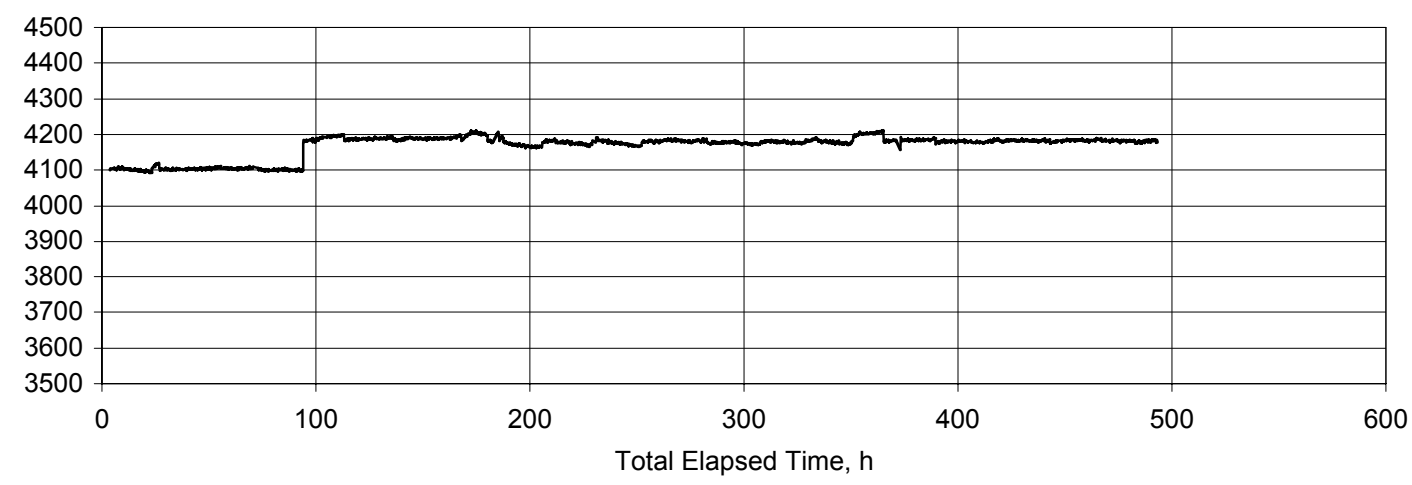

Figure 7.-Calculated specific impulse as a function of time.

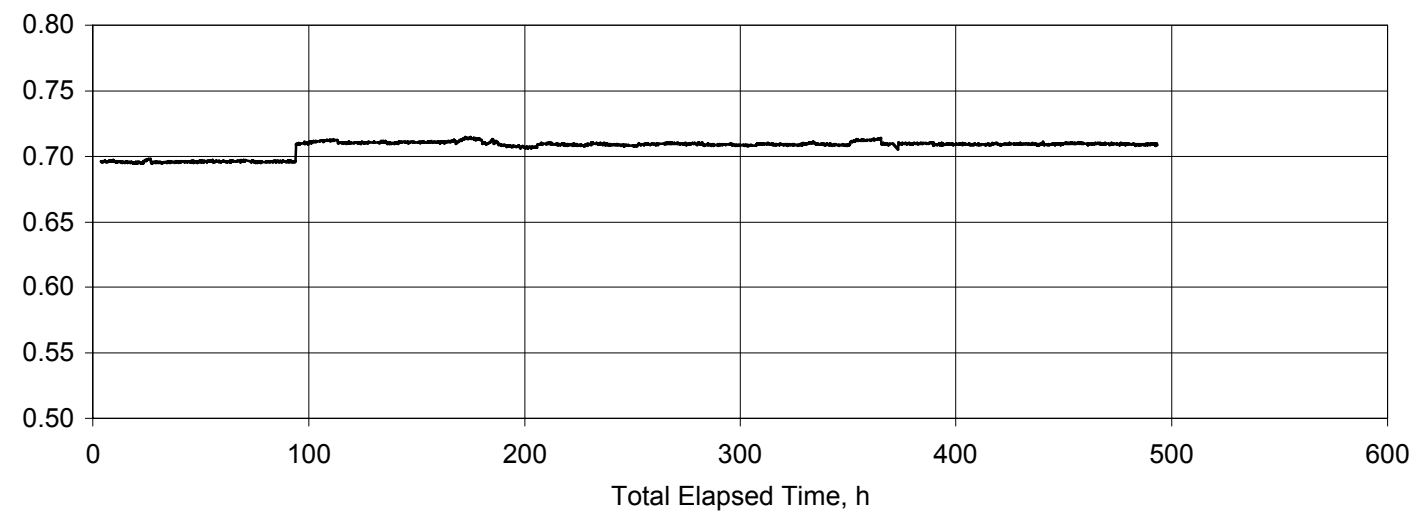

Figure 8.-Calculated thrust efficiency as a function of elapsed time.

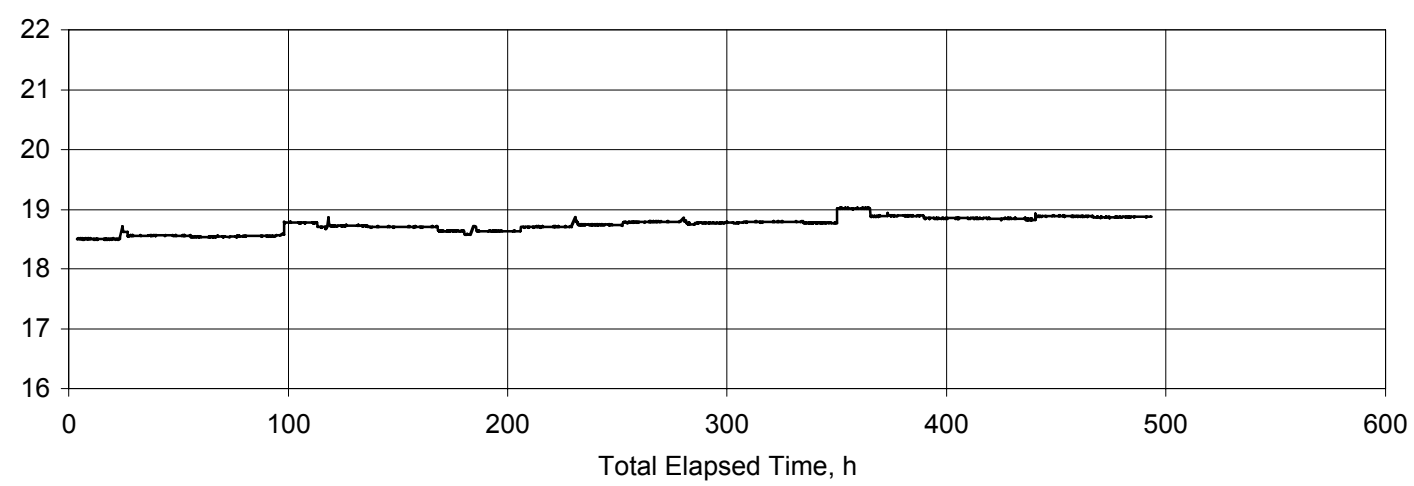

Figure 9.-Discharge current as a function of time. 


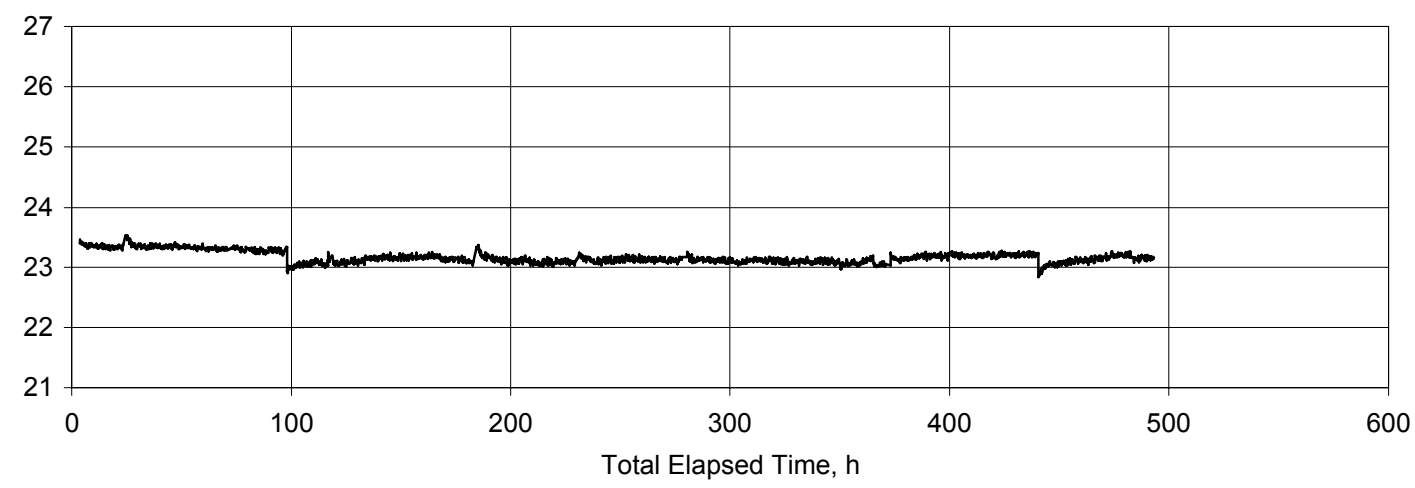

Figure 10.-Discharge voltage as a function of time.

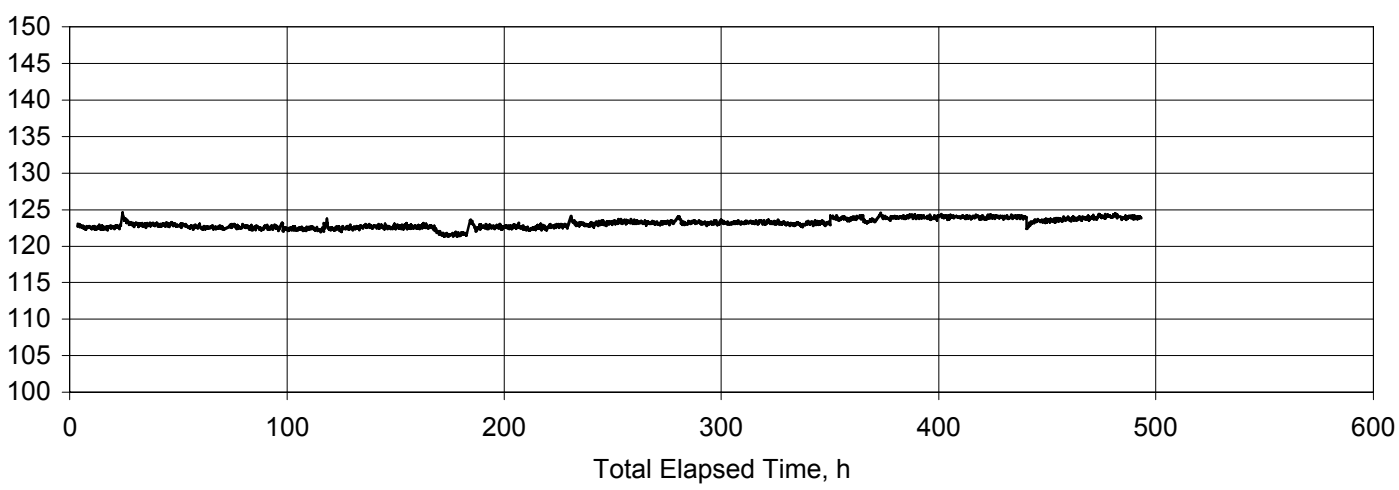

Figure 11.-Discharge losses as a function of time.

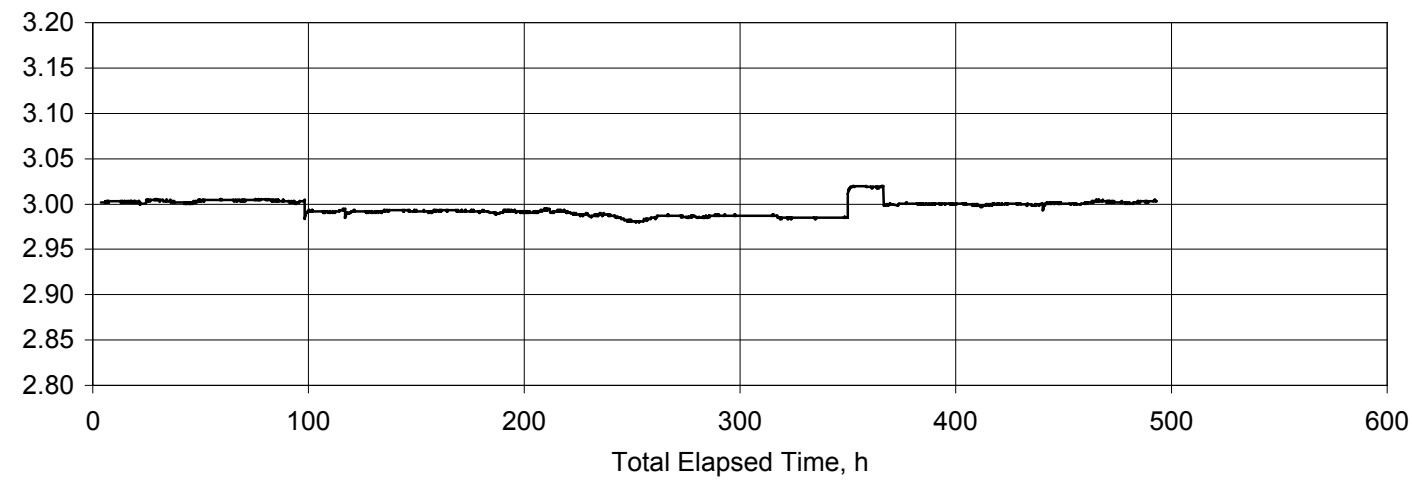

Figure 12.-Neutralizer keeper current as a function of time. 


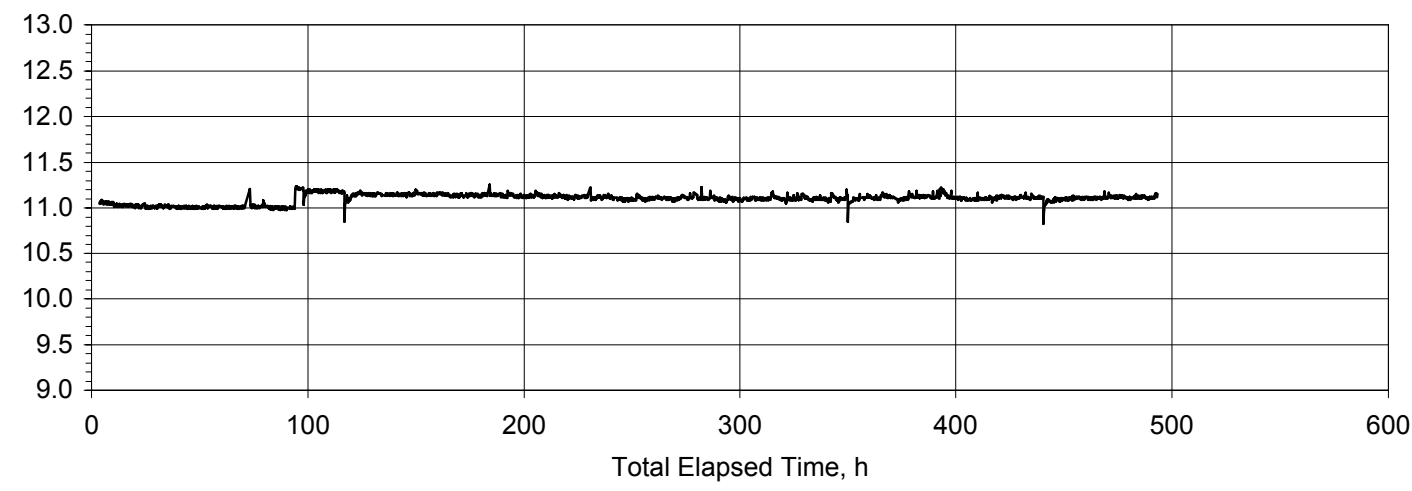

Figure 13.-Neutralizer keeper voltage as a function of time.

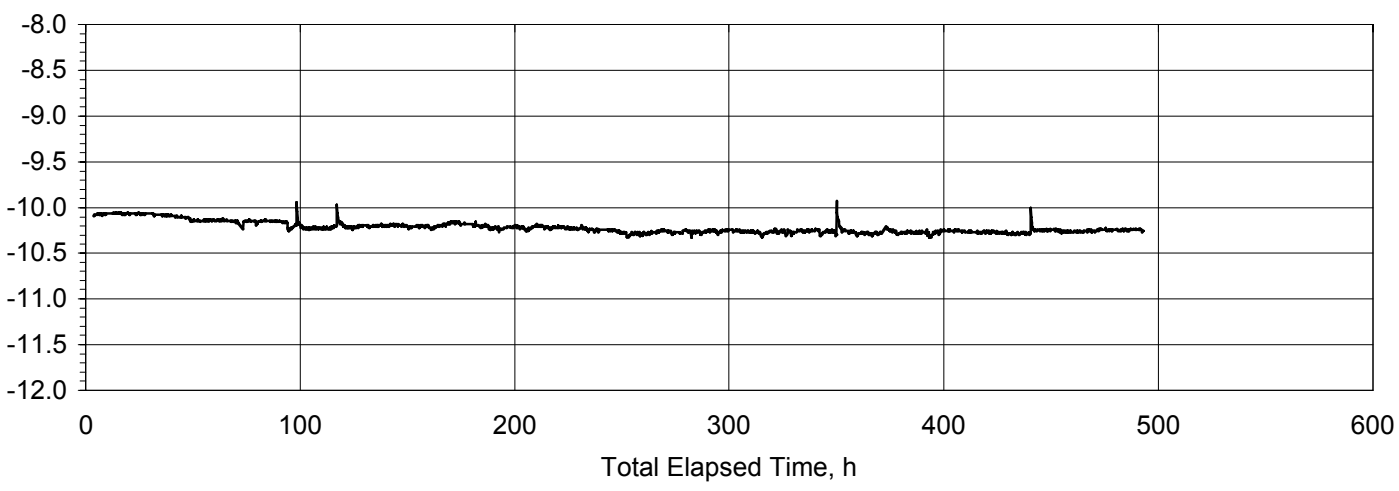

Figure 14. - Coupling voltage as a function of time.

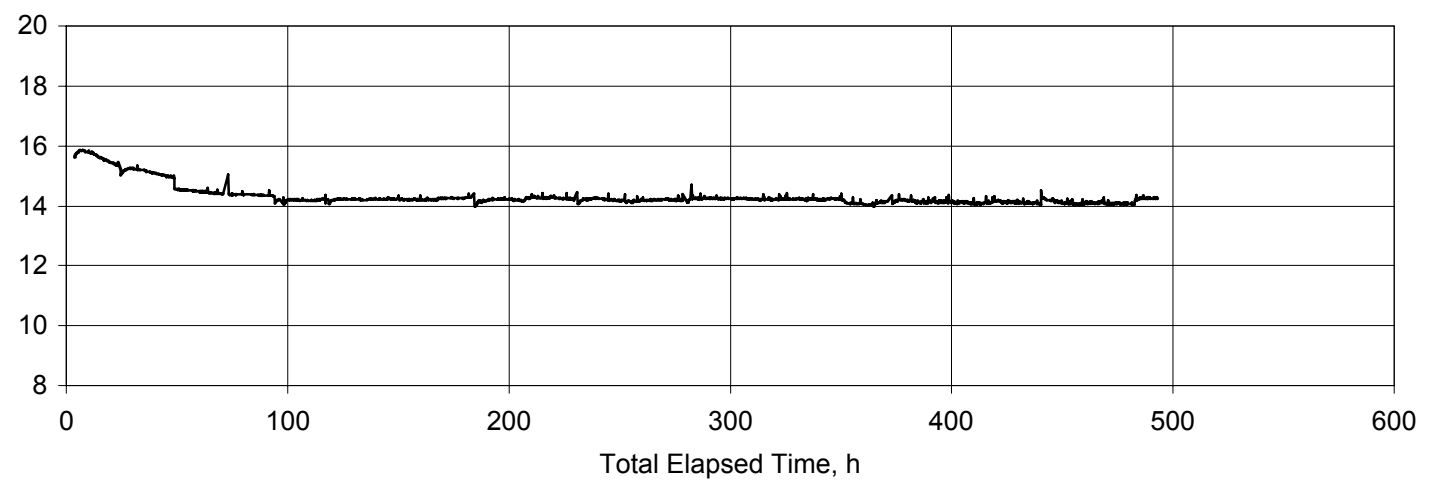

Figure 15.-Accelerator current as a function of time. 


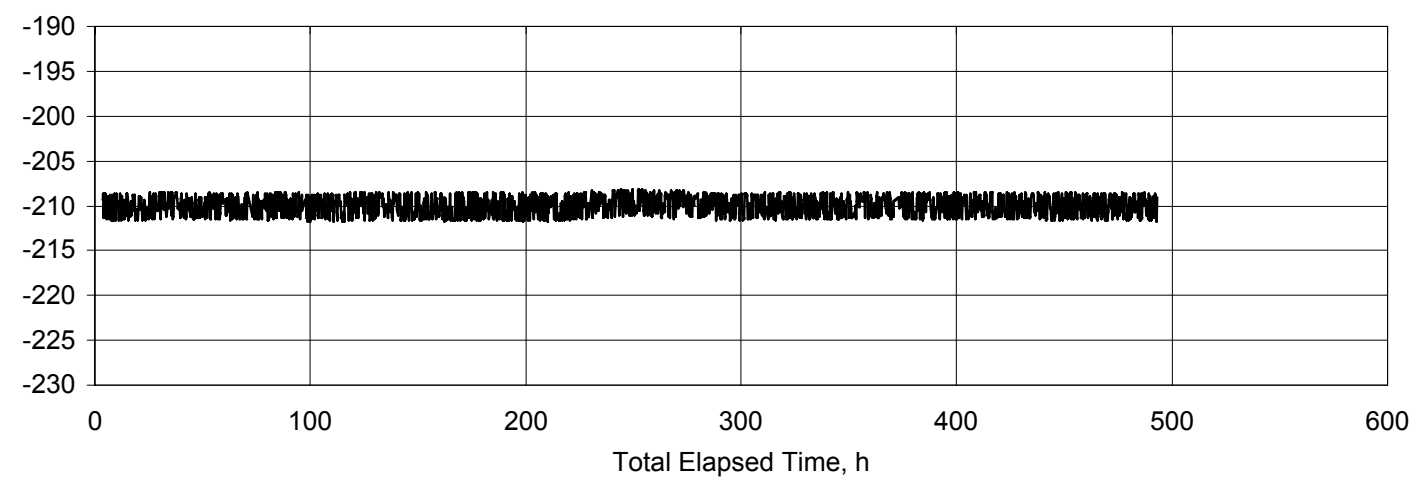

Figure 16.-Accelerator voltage as a function of time.

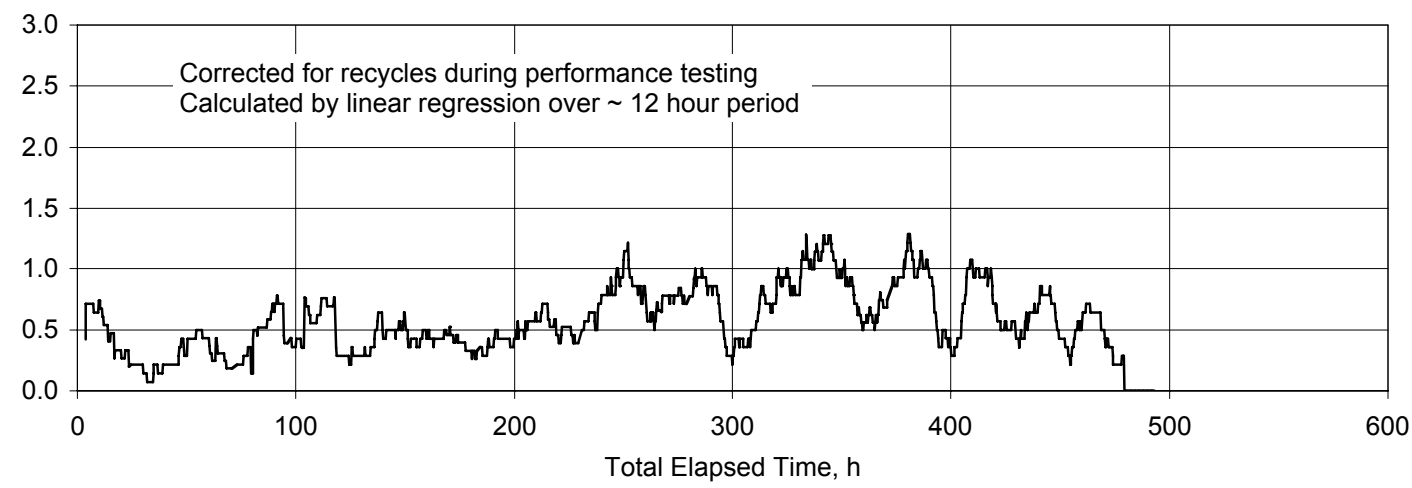

Figure 17.- Recycle rate as a function of time.

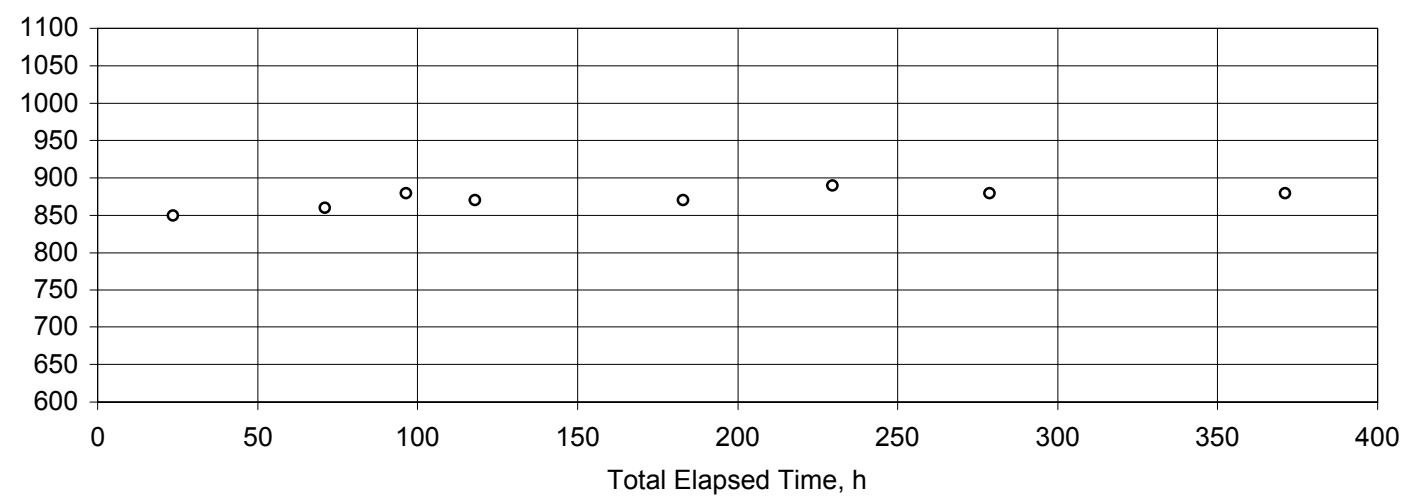

Figure 18.- Impingement limited total voltage at full power as a function of time. 


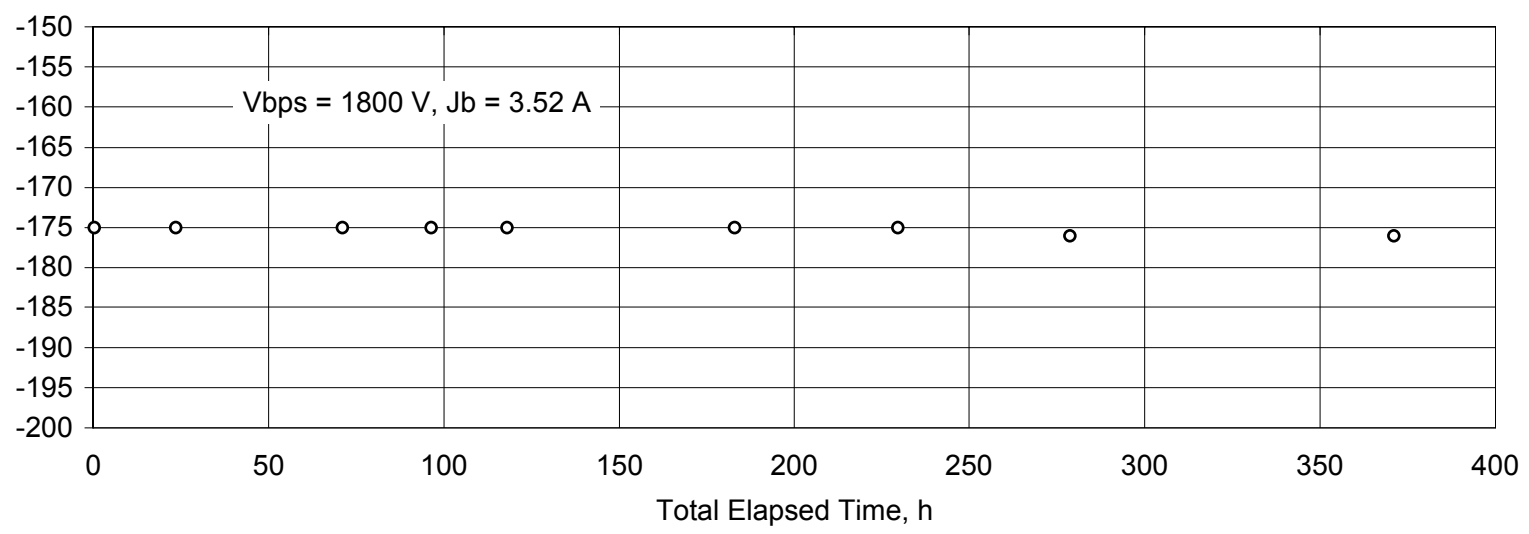

Figure 19.-Electron backstreaming limit as a function of time.

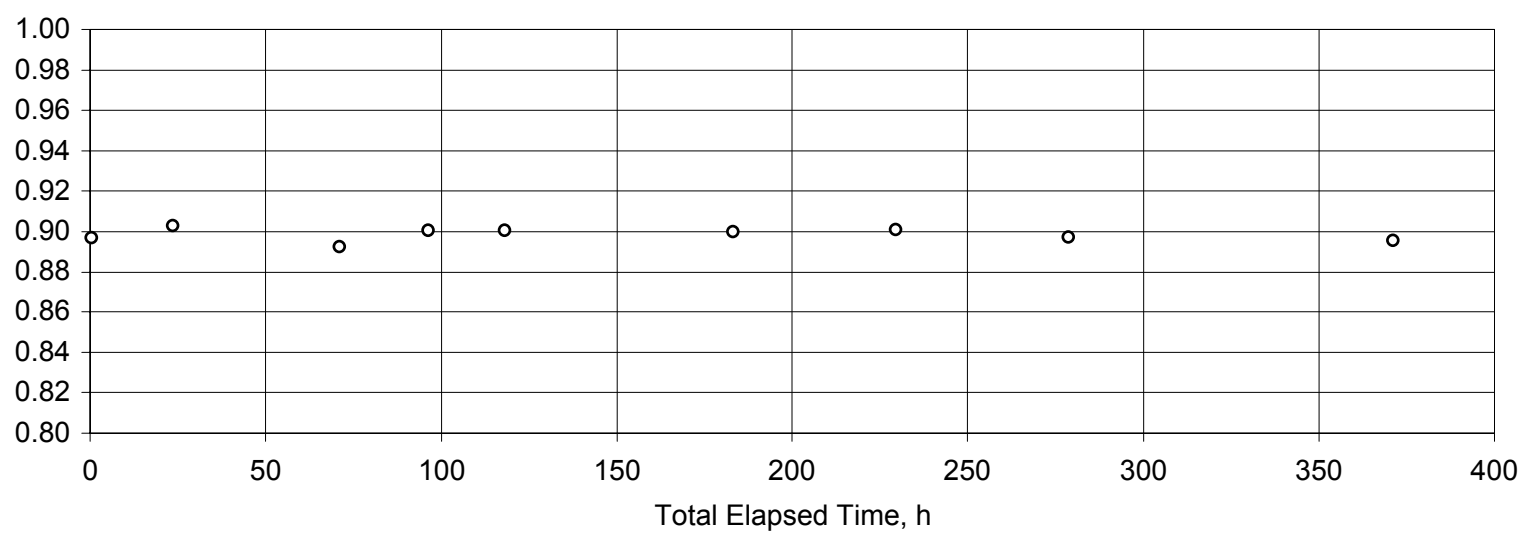

Figure 20.- Screen grid ion transparency as a function of time. 


\begin{tabular}{|c|c|c|c|}
\hline \multicolumn{3}{|c|}{ REPORT DOCUMENTATION PAGE } & $\begin{array}{l}\text { Form Approved } \\
\text { OMB No. 0704-0188 }\end{array}$ \\
\hline \multicolumn{4}{|c|}{$\begin{array}{l}\text { Public reporting burden for this collection of information is estimated to average } 1 \text { hour per response, including the time for reviewing instructions, searching existing data sources, } \\
\text { gathering and maintaining the data needed, and completing and reviewing the collection of information. Send comments regarding this burden estimate or any other aspect of this } \\
\text { collection of information, including suggestions for reducing this burden, to Washington Headquarters Services, Directorate for Information Operations and Reports, } 1215 \text { Jefferson } \\
\text { Davis Highway, Suite 1204, Arlington, VA 22202-4302, and to the Office of Management and Budget, Paperwork Reduction Project (0704-0188), Washington, DC } 20503 \text {. }\end{array}$} \\
\hline 1. AGENCY USE ONLY (Leave blank) & $\begin{array}{l}\text { 2. REPORT DATE } \\
\text { September } 2005\end{array}$ & 3. REPORT TYPE & $\begin{array}{l}\text { D DATES COVERED } \\
\text { echnical Memorandum }\end{array}$ \\
\hline \multicolumn{3}{|c|}{$\begin{array}{l}\text { 4. TITLE AND SUBTITLE } \\
\text { Status of the NEXT Ion Thruster Long Duration Test }\end{array}$} & \multirow{2}{*}{$\begin{array}{l}\text { 5. FUNDING NUMBERS } \\
\text { WBS-22-800-92-71 }\end{array}$} \\
\hline \multicolumn{3}{|c|}{$\begin{array}{l}\text { 6. AUTHOR(S) } \\
\text { Michael M. Frandina, Lynn A. Arrington, George C. Soulas, Tyler A. Hickman, } \\
\text { and Michael J. Patterson }\end{array}$} & \\
\hline \multicolumn{3}{|c|}{$\begin{array}{l}\text { 9. SPONSORING/MONITORING AGENCY NAME(S) AND ADDRESS(ES) } \\
\text { National Aeronautics and Space Administration } \\
\text { Washington, DC 20546-0001 }\end{array}$} & $\begin{array}{l}\text { 10. SPONSORING/MONITORING } \\
\text { AGENCY REPORT NUMBER } \\
\text { NASA TM-2005-213869 } \\
\text { AIAA-2005-4065 }\end{array}$ \\
\hline
\end{tabular}

\section{SUPPLEMENTARY NOTES}

Prepared for the 41st Joint Propulsion Conference and Exhibit cosponsored by the AIAA, ASME, SAE, and ASEE, Tucson, Arizona, July 10-13, 2005. Michael M. Frandina and Lynn A. Arrington, QSS Group, Inc., 21000 Brookpark Road, Cleveland, Ohio 44135; and George C. Soulas, Tyler A. Hickman, and Michael J. Patterson, NASA Glenn Research Center. Responsible person, Lynn A. Arrington, organization code RPP, 216-977-7486.

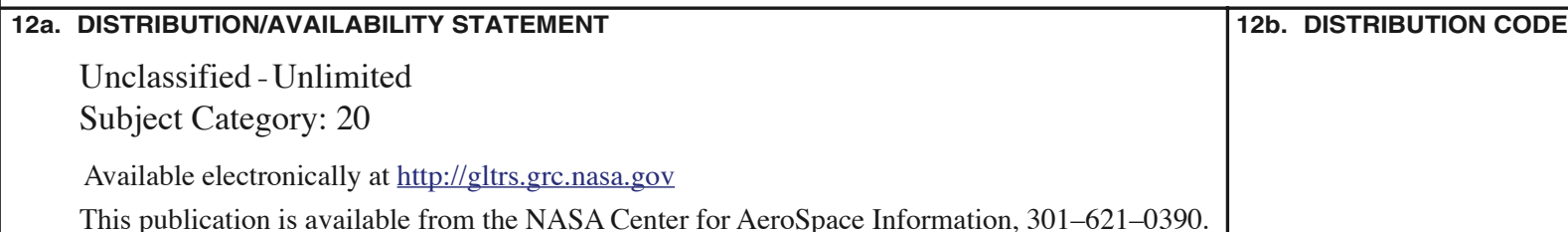

\section{ABSTRACT (Maximum 200 words)}

The status of NASA's Evolutionary Xenon Thruster (NEXT) Long Duration Test (LDT) is presented. The test will be conducted with a $36 \mathrm{~cm}$ diameter engineering model ion thruster, designated EM3, to validate and qualify the NEXT thruster propellant throughput capability of $450 \mathrm{~kg}$ xenon. The ion thruster will be operated at various input powers from the NEXT throttle table. Pretest performance assessments demonstrated that EM3 satisfies all thruster performance requirements. As of June 26, 2005, the ion thruster has accumulated 493 hours of operation and processed $10.2 \mathrm{~kg}$ of xenon at a thruster input power of $6.9 \mathrm{~kW}$. Overall ion thruster performance, which includes thrust, thruster input power, specific impulse, and thrust efficiency, has been steady to date with very little variation in performance parameters.

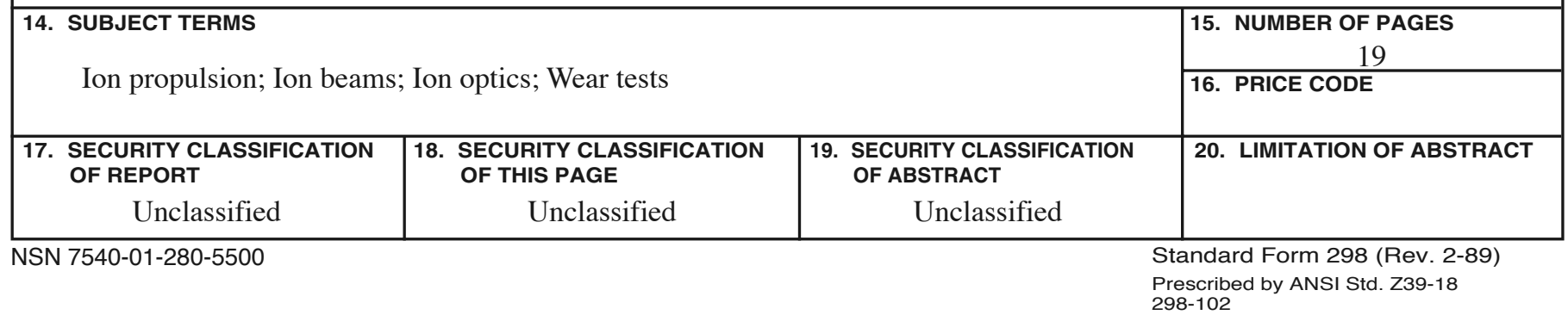



